\title{
SPRINKLER IRRIGATION OF PASTURE FOR DAIRY BEEF BULLS
}

\author{
W. C. WEEDA and C. D U R I N G \\ Ruakura Agricultural Research Centre, Hamilton
}

\section{A bstract}

Over the period 1953-1963 with full utilization of pasture by cattle but not in self-contained farmlets, the production of irrigated pasture from December to March inclusive was about $8000 \mathrm{~kg}$ $\mathrm{DM} /$ ha. Under full utilization but on self-contained units, which necessitated high grazing pressures, production during the four summer months fell to $6000 \mathrm{~kg} \mathrm{DM} / \mathrm{ha}$. White clover became dominant and perennial ryegrass was drastically thinned out. Likely steps to' overcome this problem are discussed.

In the two full seasons' from 1971 'to 1974 animal performance was as follows:

\begin{tabular}{|c|c|c|c|c|}
\hline \multirow[b]{2}{*}{ Animals/ha $\quad \ldots .}$. & \multicolumn{2}{|c|}{ No Irrigation } & \multicolumn{2}{|c|}{$\begin{array}{c}30 \% \text { of } \\
\text { Farm Irrigated }\end{array}$} \\
\hline & 4.82 & 5.39 & 5.39 & 5.98 \\
\hline $\begin{array}{l}\text { production }(\mathrm{kg} / \mathrm{ha}) \\
\text { Conversion. ratio }\end{array}$ & 872 & 917 & 952 & .960 \\
\hline $\begin{array}{l}(\underset{\mathrm{kg}}{\mathrm{kg}} \mathrm{p} \text { a s u re } \\
\text { hot carcass) }\end{array}$ & 15.4 & 14.0 & 14.6 & 14.5 \\
\hline
\end{tabular}

Because of long winters in the South Island, conversion ratios are expected to be higher than in the experiment described. However, given reasonable prices, dairy beef under irrigation should still be highly profitable.

\section{INTRODUCTION}

ProviSion of summer feed for stock can be a major problem in a drought 'and sprinkler irrigation can help in overcoming it.

Fairly consistent pasture yield responses to sprinkler irrigation have been obtained, in the Waikato, which may surprise many, since the average annual rainfall is $1200 \mathrm{~mm}$ (Hopewell, 1960). During the last 26 years the average irrigation requirement, when irrigating at a 25 to $30 \mathrm{~mm}$ moisture deficit, was $270 \mathrm{~mm}$ per year. The annual irrigation requirement fell below $250 \mathrm{~mm}$ in only 6 of those 26 years.

From 1953. to 1963 the response of pasture to sprinkler irrigation was measured on Hamilton clay loam. The average was about $4600 \mathrm{~kg} \mathrm{DM} /$ ha under lenient cattle grazing. Under these condi- 
tions the production of irrigated pasture from December to March inclusive averaged $8000 \mathrm{~kg} \mathrm{DM} /$ ha, ranging from 7200 to 9100 $\mathrm{kg} \mathrm{DM} / \mathrm{ha}$. The non-irrigated pasture yield for this period ranged from 1300 to $6200 \mathrm{~kg} \mathrm{DM} / \mathrm{ha}$ with an average of $4000 \mathrm{~kg} \mathrm{DM} / \mathrm{ha}$ Irrigation increased summer pasture growth substantially and also greatly reduced its variability.,

Whether sprinkler irrigation is going to be worth while depends to a large extent on what this extra pasture growth is used for and how efficiently it is converted into saleable products.

In dairy beef farming weaners are usually bought in November or December and two generations of cattle are on the farm in late spring and early summer. It was considered that in this situation irrigation might be very beneficial, as it would ensure an adequate supply of high quality feed at a time when stock requirements are high and pasture yields quite variable.

Some preliminary management studies were carried out and the results were reported to the 1972 Ruakura Farmers' Conference (During and Weeda, 1972).

Friesian calves, born in. July or August, were hand-reared and stocked intensively from November onwards. They were fed as far as possible to appetite at all times except for about two months in winter. It was found that, if well grown rising yearlings were fed just above maintenance requirements from mid-June to midAugust, the loss of potential liveweight gain could be recovered through compensatory growth. This reduced the hay requirement to about five or six bales per animal per year and made it possible to graze more pasture in spring, at a time of high cattle weight gains and good conversion efficiency. In summer cattle growth rates and conversion efficiency decreased, even when cattle were fed to appetite. This trend was more marked in steers than in bulls and cryptorchids, presumably because the steers put on more fat. A comparison of carcass composition showed a trimmable carcass fat content of ${ }^{6} 11.6 \%$ for steers and $6.6 \%$ for bulls and cryptorchids. Carcass .weights of 180 to $250 \mathrm{~kg}$ were obtained with 16- to 17-months-old Friesian steers, bulls or cryptorchids.

In the writers' experience, using the then current costs and prices, it was more profitable to carry the animals to a carcass weight of $225 \mathrm{~kg}$ than to finish them at a lighter weight and at a higher stocking rate.

Given, then, that good management will enable adequate feeding of calves in most summers, irrigation of part of the farm will allow two changes in management: a delay in the killing dates of the yearlings, and higher stocking rates, Also, since irriga- 
tion reduces the variability of pasture production in summer, planning of killing dates becomes easier. Further, the feed produced is of high quality, so that, in all, an extra increment of pasture produced by the application of water should be utilizable at an efficiency just as high as or higher than that reached for basic pasture growth without irrigation.

\section{EXPERIMENTAL DESIGN}

The experiment, begun in summer 1971-2, had the following treatments:

\begin{tabular}{|c|c|c|c|c|c|}
\hline Treatments & & & & $\begin{array}{l}\text { Stocking Rate } \\
\text { (animals/ha) }\end{array}$ & $\begin{array}{l}\text { Animals } \\
\text { per Farmlet }\end{array}$ \\
\hline 1. No irrigation & & $\ldots$ & . & 4.82 & 19 \\
\hline 2. No irrigation & $\ldots$ & & $\ldots$ & 5.39 & 21 \\
\hline 3. $30 \%$ irrigated & $\ldots$ & $\ldots$ & & 5.39 & 21 \\
\hline 4. $30 \%$ irrigated & $\ldots$ & $\ldots$ & & 5.98 & 23 \\
\hline
\end{tabular}

In the third year, which is not yet completed, stocking rates in Treatments 3 and 4 were equal at 5.4 animals/ha, with Treatment 4 receiving a fungicide.

Friesian cryptorchid calves, 3.5 to 4 months of age, with average weights of 100 to $120 \mathrm{~kg}$, were brought in in mid-November, and from that time onwards, the la-year-old animals were gradually disposed of. Hay was cut on 16 lo $25 \%$ of each farmlet, the proportion increasing with rate of stocking. Urea at $40 \mathrm{~kg} / \mathrm{ha} \mathrm{N}$ equivalent was applied in late autumn to early winter.

The stocking rates were calculated by dividing expected pasture yield by estimated intakes. Irrigation of $30 \%$ of the area was estimated to increase annual pasture production over the whole farm by $10 \%$, hence the $10 \%$ difference between stocking rates of irrigated and non-irrigated treatments.

The grazing rotation in general varied with rate of pasture growth, except in late winter. It was 4 to 5 weeks in autumn, lengthening to 7 weeks in mid-May, but in mid-August, when the rate of growth was still low, it was shortened to 2 to 3 weeks to anticipate the increase in pasture growth rate in September. At this stage paddocks were still grazed hard, the pasture was short when cattle entered the paddock, and bloat danger was at its most acute, but in spite of high grazing pressures cattle made high weight gains from about August 20 onwards.

Standing pasture dry matter was measured before cattle entered the paddock and again immediately after grazing, the difference 
being pasture eaten, destroyed, or lost by decay. Pasture yields can also be calculated from these data.

Cattle were weighed at two to three-weekly intervals.

\section{RESULTS AND DISCUSSION}

\section{STOCK PERFORMANCE}

Data on cattle intakes and live weight gains allowed the estimation of conversion ratios (Table 1). They are generally satisfactory except in winter, and in the last two summers and autumns in the unirrigated treatments.

Irrigation can be justified only if good growth rates of cattle are achieved in summer. This has been possible with bulls or cryptorchids, but not with steers as explained earlier. However, none of the growth rates are as good as those obtained in spring.

Table 2 summarizes the most important results of the first two years, production of carcass meat, average slaughter dates, apparent intakes of cattle and conversion ratios. Under the conditions of this experiment each irrigated hectare produced an extra 200 $\mathrm{kg}$ carcass weight. In part this difference may be a function of the higher average stocking rates on the irrigated farms. A comparison at the same stocking rate (Treatments 2 and 3) shows a difference of some $120 \mathrm{~kg}$ carcass weight per irrigated hectare.

The ability of cattle to make compensatory growth is already exploited by feeding cattle very little hay in winter. Additional

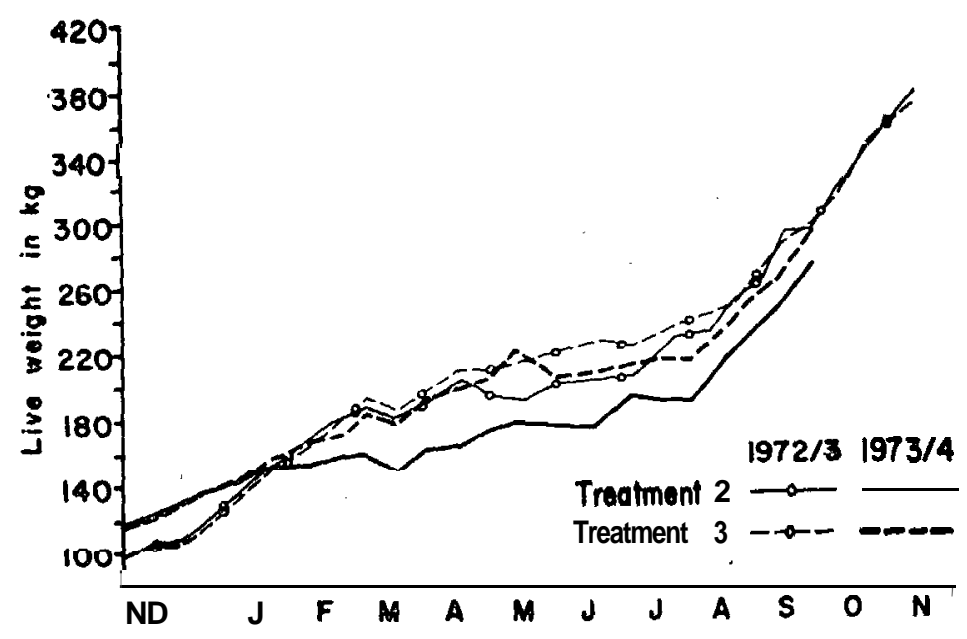

Fig. 1: Cattle liveweights of Treatments 2 and 3. 
TABLE 1: APPARENT CATTLE INTAKES AND LIVEWEIGHT GAINS (kg/day)

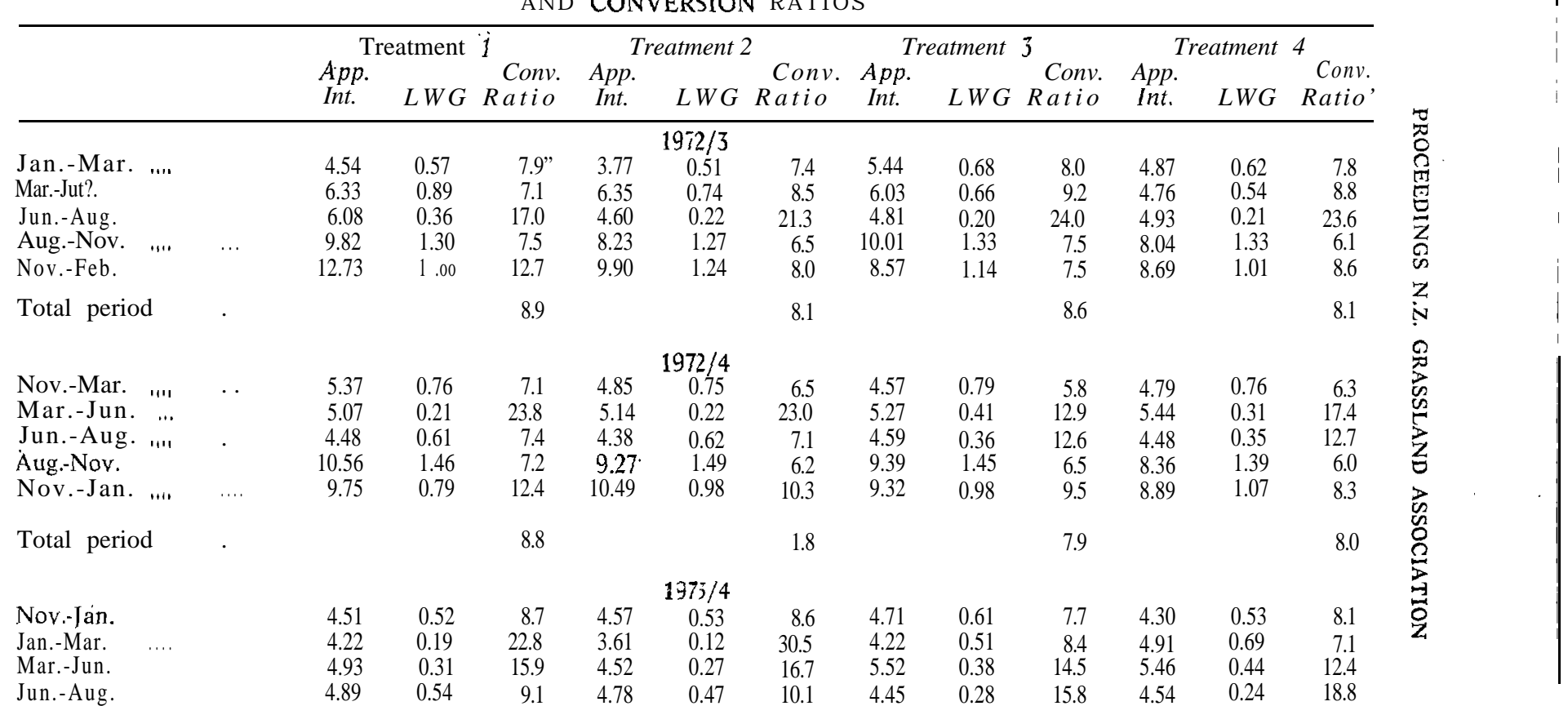

* Calculated from the total apparent intakes and liveweight gains for the particular period, not from the daily values as shown in this table. 
TABLE 2: TRIAL RESULTS (AVERAGE OF TWO YEARS)

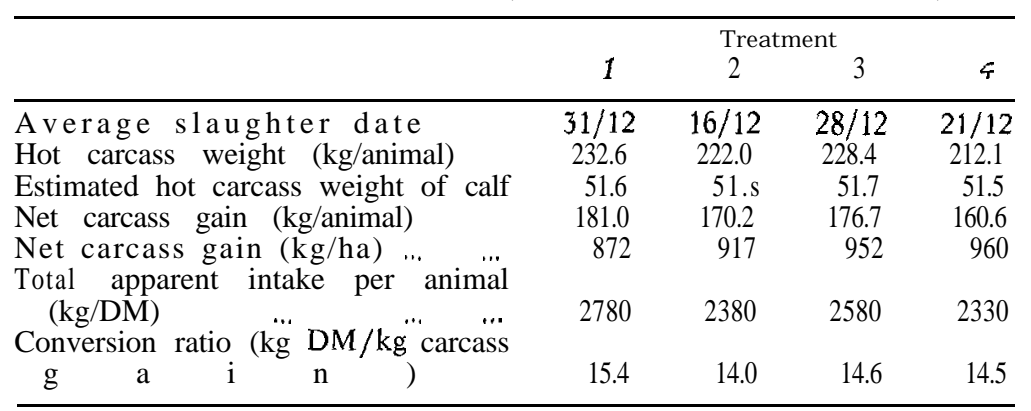

compensatory growth also occurred at other times of the year, as is shown in Fig. 1. In autumn 1973, a liveweight difference of more than $20 \mathrm{~kg}$ developed between Treatments 2 and 3. By early spring this difference had disappeared. In autumn 1974, the liveweight difference between these two treatments was approximately $40 \mathrm{~kg}$. This difference was reduced to $20 \mathrm{~kg}$ by early spring and remained at this level during spring. These results show that, in a system where compensatory growth is already being exploited, liveweight differences, obtained early in the animal's life, can later on easily be reduced or entirely eliminated.

Figure 2 shows the cattle liveweights in Treatment 3, together with the target liveweights as derived from preliminary trials

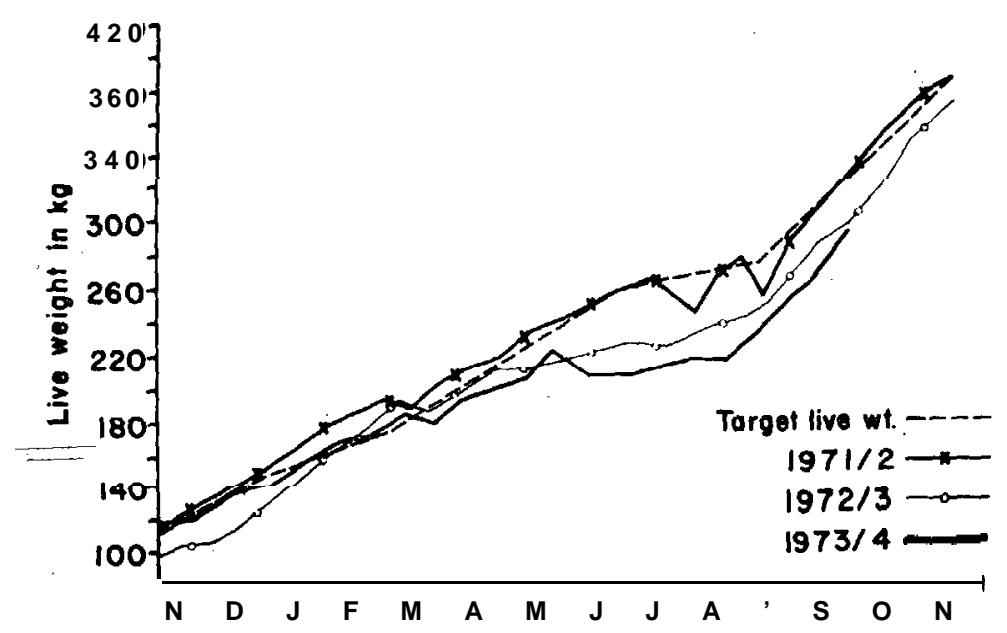

FIG. 2: Target liveweights and actual liveweights in Treatment 3. 
(During and Weeda, 1972). These targets may be realistic in most years, because, unless summer drought is severe, as in 1974, short periods of feed shortages can be absorbed by the system.

With dairy beef, an overlap of generations occurs from November to February. At the stocking rates used in these trials, cattle were not held for a complete second summer in order that they could be finished in the following autumn. This time-honoured custom of keeping yearlings over their second summer seems difficult to justify by the trial results, because at no time did we measure an autumn flush so large that there was an appreciable surplus above the requirements of the calves. The timing of the disposal of the yearlings is the most difficult problem in the management of an intensive system of this type. It is not made easier by the need for forward bookings at abattoirs and freezing works or by industrial disputes. The aim was to feed calves to appetite during late spring and summer. Only what could be regarded as truly surplus to their requirements was set aside for the yearlings, but they also were expected to maintain a high growth rate and therefore those kept on had to be fed to appetite. Inevitably this required a large reduction in the number of yearlings, and the timing of this operation was based largely on predictions of pasture growth in summer, a time when such predictions are almost impossible to make. Experience would suggest that it is best to estimate pasture growth at slightly below the known average for summer. This was done in this experiment,

P A S T U R E

Pasture yields for the period December to March inclusive are - shown in Table 3, together with yields obtained from 1953 to 1964.

From 1953 to 1964 the trials were not self-contained, cattle could be removed, rotation was long and grazing pressure lenient.

Although the present grazing management is reasonably efficient for the production of good animals, the same management has led

TABLE 3: SUMMER PASTURE YIELDS (DEC.-MAR. INCL.) $\mathrm{kg} \mathrm{DM} / \mathrm{ha}$

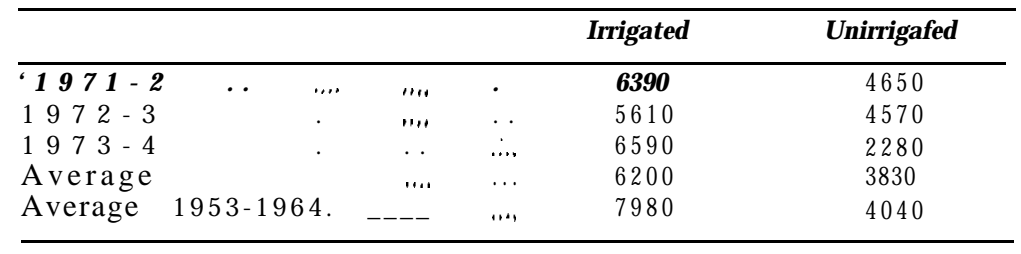


to a low output of herbage in summer. At that time long daylength and high temperature combined with adequate moisture should give very high pasture growth. Earlier, both perennial ryegrass (Lolium perenne) and cocksfoot (Dactylis glomerata) persisted over summer and contributed to production. In the present experiment cocksfoot has disappeared, the survival rate of perennial ryegrass is low, and overdrilling of this grass in autumn has become a regular, necessary, and costly practice. In summer most of the pasture yield comes from white clover (Trifolium repens). Other grass species are being tried and preliminary results show 'some promise for the new ryegrass cultivar 'Grasslands Nui'.

The introduction and maintenance of pasture species that will grow well in hot summers on irrigated pasture may not be a problem entirely confined to the northern part of the North Island. There is evidence that long rotation and lenient grazing help perennial ryegrass to survive (Weeda, 1965). It. is also likely that other species that contribute more in summer than perennial ryegrass, such as red clover ( $T$. pratense) and cocksfoot will also thrive under the same treatment. The problem is how to combine very high stocking rates that are necessary to utilize the feed grown with maximum production of irrigated pastures. Where only a part of the farm is irrigated, special treatment of irrigated areas, and sacrifice areas on the remaining farm, may benefit overall farm production. In the North Island at least, a study of management to increase the output of irrigated pastures without reducing the efficiency of their utilization by cattle seems to have high priority. However, the fact that, in an area of relatively high rainfall, irrigation can increase the production of carcass beef appreciably indicates that with good management, and given reasonable prices, the application of water in districts drier than the Waikato must be profitable.

\section{ACKNOWLEDGEMENTS}

Thanks are due to B. G. Croy, D. F. Howard, E. J. Thomsen and C. Sturgeon for technical assistance, to the staff of the Ruakura Soil Research Station for dry matter determinations and herbage dissections, and to the staff of the abattoir of the Ruakura Animal Research Station for carcass data.

\section{REFERENCES}

During, C.; Weeda, W. C., 1972. Proc. Ruakura Fmrs' Conf.: 100-8

Hopewell, H. G., 1960. N.Z. Il Agric., 100; 77.

Weeda, W. C., 1965. N.Z. Jl agric. Res., 8: 1060-g. 